\title{
Implementation of Maximum Power Point Tracking (MPPT) Technique on Solar Tracking System Based on Adaptive Neuro- Fuzzy Inference System (ANFIS)
}

\author{
Imam Abadi ${ }^{1 *}$, Choirul Imron ${ }^{2}$, Mardlijah $^{2}$, Ronny D. Noriyati ${ }^{1}$ \\ ${ }^{1}$ Department of Engineering Physic, Institut Teknologi Sepuluh Nopember Surabaya, Indonesia \\ ${ }^{2}$ Department of Mathematic, Institut Teknologi Sepuluh Nopember Surabaya, Indonesia
}

\begin{abstract}
Characteristic I-V of photovoltaic is depended on solar irradiation and operating temperature. Solar irradiation particularly affects the output current where the increasing solar irradiation will tend to increase the output current. Meanwhile, the operating temperature of photovoltaic module affects the output voltage where increasing temperature will reduce the output voltage. There is a point on the I-V curve where photovoltaic modules produce maximum possible output power that is called Maximum Power Point (MPP). A technique to track MPP on the I-V curve is known as Maximum Power Point Tracking (MPPT). In this study, the MPPT has been successfully designed based on Adaptive Neuro-Fuzzy Inference System (ANFIS) and integrated with solar tracking system to improve the conversion efficiency of photovoltaic modules. The designed ANFIS MPPT system consists of current and voltage sensors, buck-boost converter, and Arduino MEGA 2560 microcontroller as a controller. Varying amounts of lamp with $12 \mathrm{~V} 10 \mathrm{~W}$ rating arranged in series is used as load. Solar tracking system that is equipped with MPPT ANFIS able to increase the output power of photovoltaic modules by $46.198 \%$ relative to the fixed system when 3 lamps is used as load.
\end{abstract}

\section{Introduction}

The main problem found in the Solar Power Generation System nowadays is low conversion efficiency of photovoltaic module. One way to improve power production from photovoltaic modules is to have it equipped with a solar tracking system. Solar tracking system will keep phovoltaic surface oriented toward sun, allow the module exposed to higher amount of solar irradiation, to produce maximum power $[1,2]$.

Characteristics of a photovoltaic cell is expressed by current versus voltage curve (I-V curve) and power versus voltage curve $(\mathrm{P}-\mathrm{V})$ that is influenced by solar irradiation level and temperature of photovoltaic module. There is a particular point on a I-V curve where photovoltaic will produce highest possilble power output called maximum power point (MPP)[3,4]. Process of finding MPP to maximize power extraction is called maximum power point tracking (MPPT). The aim of this study is to develop a MPPT for photovoltaic system equipped with solar tracking system based on Adaptive Neuro-Fuzzy Inference System (ANFIS).

\subsection{Photovoltaic}

Photovoltaic is a semiconductor device that exhibit photovoltaic effect that convert sunlight energy into electrical energy.

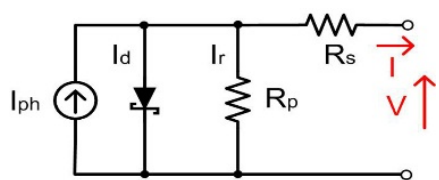

Fig. 1. Single-diode model of photovoltaic cell including parallel and series resistances. [4].

The equation that describe the single-diode model presented in Fig. 1 is

$$
\begin{gathered}
I=I_{p v}-I_{o}\left\{\exp \left[\frac{V+I R_{s}}{a V_{t}}\right]-1\right\}-\frac{V+I R_{s}}{R_{p}} \\
V_{t}=\frac{N_{s} k T}{q}
\end{gathered}
$$

where :

$\mathrm{I}_{\mathrm{pv}}$ is photovoltaic current (A),

$\mathrm{I}_{0} \quad$ is saturation current $(\mathrm{A})$,

$\mathrm{q}$ is electron charge $\left(1,602 \times 10^{-19} \mathrm{C}\right)$,

I is current at the terminal of photovoltaic (A),

$\mathrm{V}$ is voltage at the terminal of photovoltaic $(\mathrm{V})$,

$\mathrm{V}_{\mathrm{t}}$ is thermal voltage $(\mathrm{V})$,

$\mathrm{k}$ is Boltzmann's constant $\left(1,381 \times 10^{-23} \mathrm{~J} / \mathrm{K}\right)$,

$\mathrm{T}$ is module temperature $(\mathrm{K})$,

$a$ is diode constant,

$\mathrm{R}_{\mathrm{s}}$ is equivalent series resistant of photovoltaic array $(\mathrm{Ohm})$

$\mathrm{R}_{\mathrm{p}}$ is equivalent parallel resistant of photovoltaic array $(\mathrm{Ohm})$

Ns is series connected photovoltaic cell,

\footnotetext{
Corresponding author:imam@ep.its.ac.id
} 
Characteristic curve of photovoltaic is depended on solar irradiation and operating temperature. Solar irradiation particularly affects the output current where increasing solar irradiation will tend to increase the output current. Meanwhile, operating temperature of photovoltaic module affects the output voltage where increasing temperature will reduce the output voltage [5].
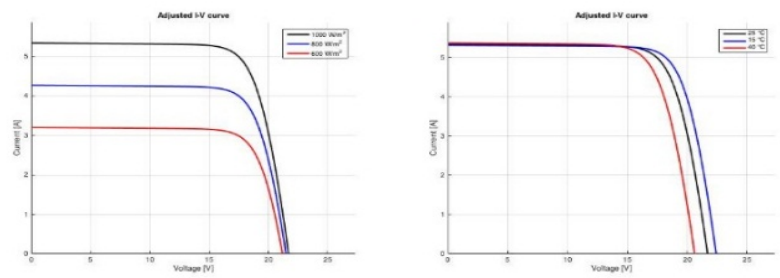

Fig. 1. Effect of solar irradiation and temperature of photovoltaic module on I-V curves[5].

\subsection{Maximum Power Point Tracking (MPPT)}

Maximum power point tracking is tracking method of MPP to obtain maximum possible power from photovoltaic during daylight. The goal of the MPPT is to match the equivalent resistance at the terminal of photovoltaic $R_{\text {eq }}$ to the optimal output resistance Ropt that is defined as [5]

$$
R_{\text {opt }}=\frac{V_{m p p}}{I_{m p p}}
$$

When $\mathrm{R}_{\mathrm{eq}}=\mathrm{R}_{\mathrm{opt}}$ condition met, the MPP is obtained thus maximum possible power will be produced by photovoltaic modules. Process for matching $\mathrm{R}_{\mathrm{eq}}$ toward $\mathrm{R}_{\mathrm{opt}}$ to obtain MPP is illustrated in Fig. 3. Slope of the straight line is the representation of $R_{e q}$ value. The intersection of straight line $\mathrm{R}_{\mathrm{eq}}$ and I-V curve is operating point of photovoltaic. MPPT will alter this operating point toward MPP. In general, MPPT is consist of a DCDC converter, a controller, and sensors. Duty cycle of the converter is used as a control variable to change the $\mathrm{R}_{\mathrm{eq}}$ value [6].

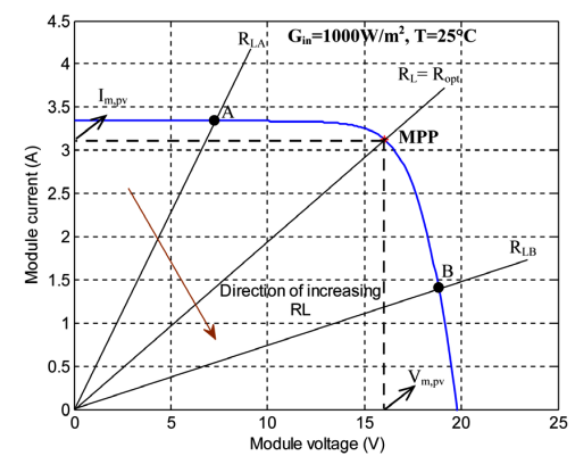

Fig. 2. Ilustration of MPP tracking on the I-V curve[5].

Open-voltage method is a MPPT technique based on observation that maximum power point voltage $V_{M P P}$ has a fixed ratio to open-circuit voltage $\mathrm{V}_{\mathrm{OC}}[6-10]$ that is defined as

$$
\frac{V_{m p p}}{V_{o c}} \cong k ; k<1
$$

Where the constant $\mathrm{k}$ is found to be between 0.7 $0.8[11]$. Flowchart diagram of open-voltage method is shown on Fig. 5.

\subsection{Buck-Boost Converter}

$\mathrm{B}$ uck-boost converter is a type of DC-DC converter that outputs voltage either less or greater than the input voltage. Relationship between input voltage $\mathrm{Vi}$, output voltage $\mathrm{Vo}$, and duty cycle $\mathrm{D}$ for buck-boost converter is stated as:

$$
V_{o}=-\frac{D}{1-D} V_{i}
$$

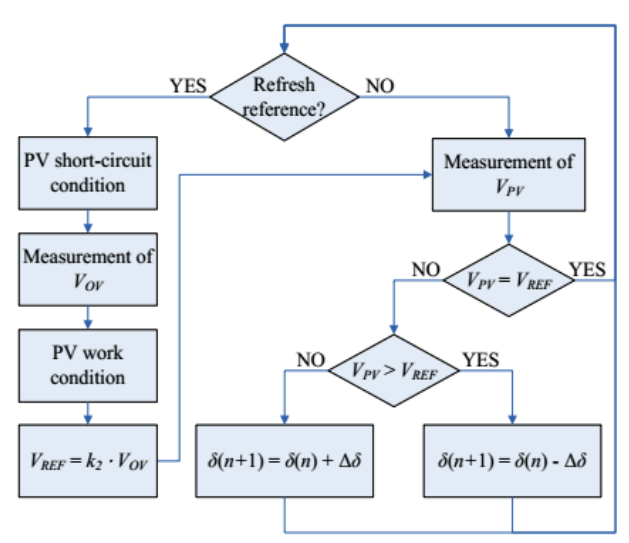

Fig. 5. Flowchart of open-voltage method[6].

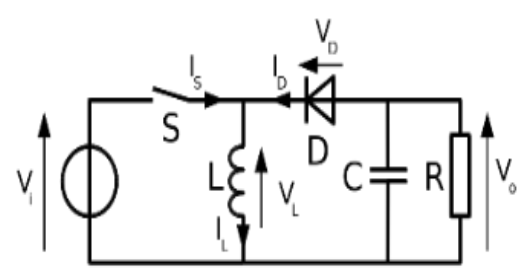

Fig. 6. Buck-boost converter.

\subsection{Adaptive Neuro-Fuzzy Inference System (ANFIS)}

ANFIS is a kind of adaptive networks that incorporate both Takagi-Sugeno Kang Fuzzy Inference System (FIS) and artificial neural network [12]. ANFIS structure is consisted of five layers represent artificial neural network architecture as illustrated in Fig. 7. The square nodes represents an adaptive parts while the circle nodes represents non-adaptive sections. Paramaters of the adaptive nodes will be changed during the training process of ANFIS $[9,10]$. 


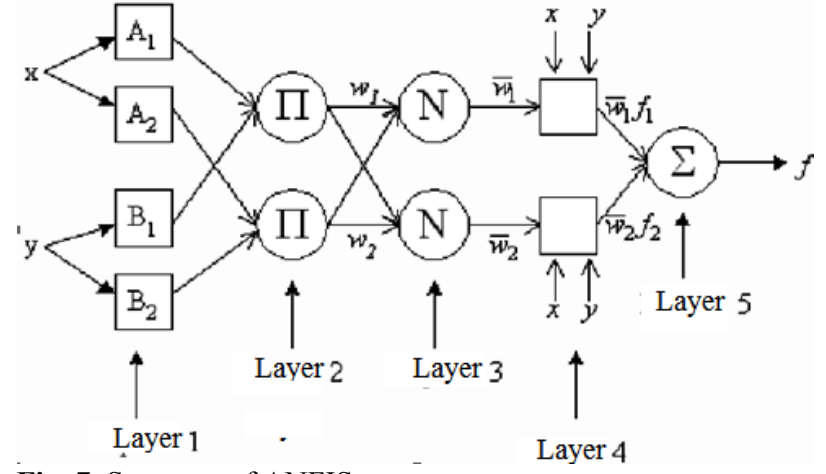

Fig. 7. Structure of ANFIS

\section{Metodology}

\subsection{Block diagram of ANFIS MPPT}

ANFIS MPPT developed in this study as displayed in Fig. 8 is consist of buck-boost converter, ANFIS MPPT controller, and voltage-current sensor.

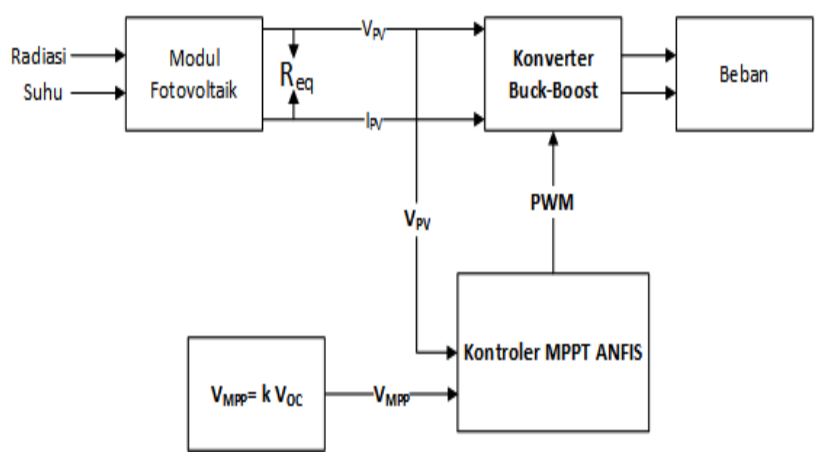

Fig. 8. Block diagram of ANFIS MPPT.

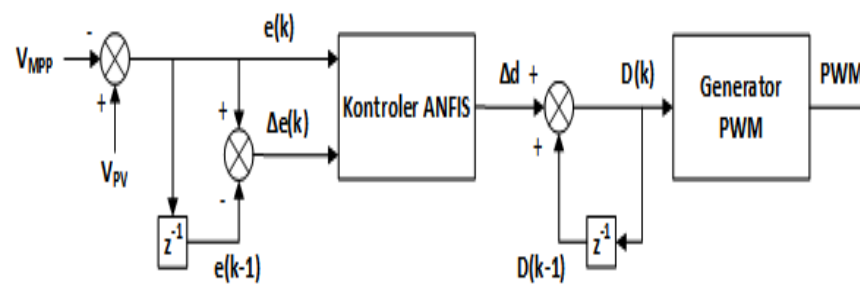

Fig. 9. Block diagram of ANFIS MPPT controller.

The proposed ANFIS MPPT is depicted in Figure 9. Error value $e$ and change of error $\Delta e$ is taken as the input for ANFIS MPPT controller defined as

$$
\begin{aligned}
& e(k)=V_{p v}(k)-V_{m p p}(k) \\
& \Delta e(k)=e(k)-e(k-1)
\end{aligned}
$$

where $e(k)$ and $e(k-1)$ are current and previous error, respectively. Maximum power point voltage $\mathrm{V}_{\mathrm{MPP}}$ is obtained using Open-voltage Method. Output of ANFIS MPPT is change of duty cycle $\Delta d(k)$ and duty cycle D value can be written as

$$
D(k)=D(k-1)+\Delta d(k)
$$

where $D(k)$ is current duty cycle and $D(k-1)$ is previous duty cycle.

\subsection{Design of ANFIS}

In this study, ANFIS is designed using MATLAB. The proposed ANFIS consists of five gaussian membership functions for each input as shown in Fig. $10 \& 11$. Moreover its output is singleton as shown in Fig. 12.

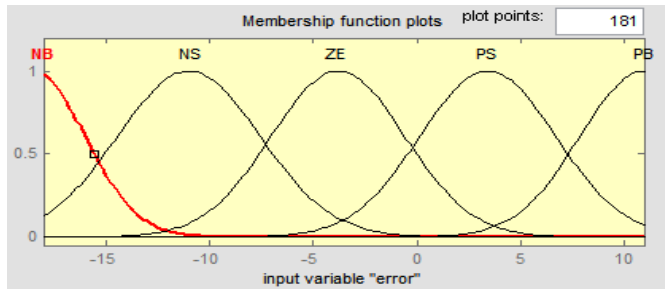

Fig. 10. Membership fuction for input (error)

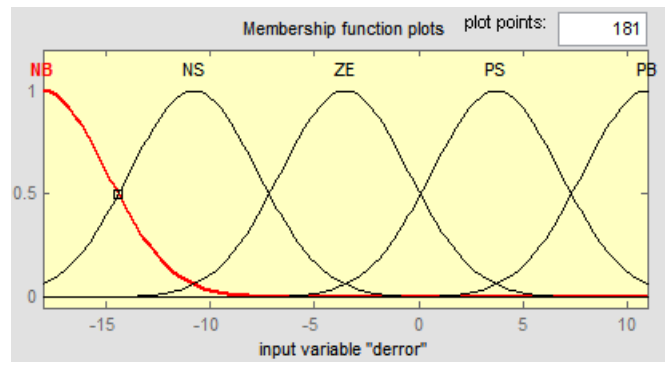

Figure 11. Membership fuction for input (change error)

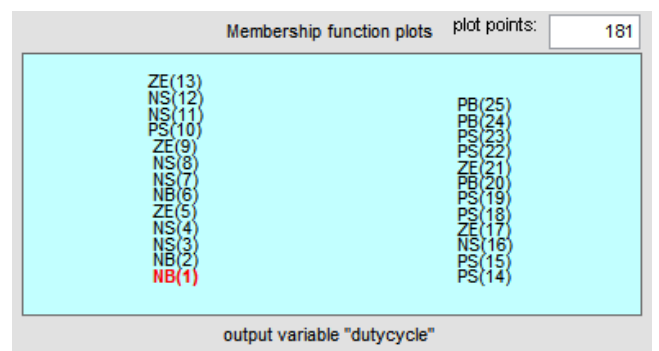

Fig. 12. Membersip function for output.

\subsection{Simulation of ANFIS MPPT}

Simulation of ANFIS MPPT is performed in PSIM 9.0 and MATLAB/Simulink. Co-simulation is carried out by implementing the ANFIS MPPT in MATLAB/Simulink, meanwhile photovoltaic module and buck-boost converter is partially run using PSIM 9.0 as seen in Figure 13. 


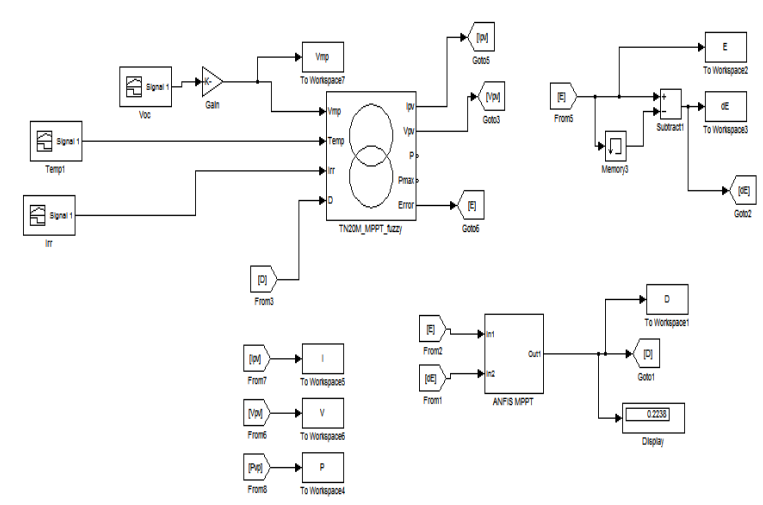

Fig. 13. ANFIS MPPT model in MATLAB/Simulink.

Table 1. Photovoltaic module specification.

\begin{tabular}{|l|l|}
\hline Model & TN-20M \\
\hline Maximum Power at STC $\left(P_{M P P}\right)$ & $20 \mathrm{~W}$ \\
\hline Maximum Power Voltage at $S T C\left(V_{M P P}\right)$ & $17,2 \mathrm{~V}$ \\
\hline Maximum Power Current at $S T C\left(I_{M P P}\right)$ & $1,16 \mathrm{~A}$ \\
\hline Open Circuit Voltage at $S T C\left(V_{O C}\right)$ & $21,5 \mathrm{~V}$ \\
\hline Short Circuit Current at $S T C\left(I_{S C}\right)$ & $1,25 \mathrm{~A}$ \\
\hline Temperature Coefficient of $V_{O C}$ & $-0,36 \% /{ }^{\circ} \mathrm{C}$ \\
\hline Temperature Coefficient of $I_{S C}$ & $0,05 \% /{ }^{\circ} \mathrm{C}$ \\
\hline Series Connected Cell per Modul & 36 \\
\hline
\end{tabular}

Table 2. buck-boost konverter specification [15].

\begin{tabular}{|l|c|}
\hline Parameter & Quantities \\
\hline Vin & $9-22 \mathrm{~V}$ \\
\hline Vout (nominal) & $14 \mathrm{~V}$ \\
\hline Iout & $1,5 \mathrm{~A}$ \\
\hline Switching Frequency & $25 \mathrm{kHz}$ \\
\hline Inductor & $193 \mu \mathrm{H}$ \\
\hline Output Capacitor & $470 \mu \mathrm{F}, 50 \mathrm{~V}$ \\
\hline Nominal resistive load & $8 \Omega$ \\
\hline
\end{tabular}

\subsection{Realization of ANFIS MPPT}

ANFIS MPPT hardware developed in this study is shown in Figure 14. In general, prototype is divided into several subsystems for the ease of realization. INA219 is used as current-voltage sensor and Arduino MEGA 2560 is functioned as controller. Specification of the buckboost converter is shown in Table 2 .

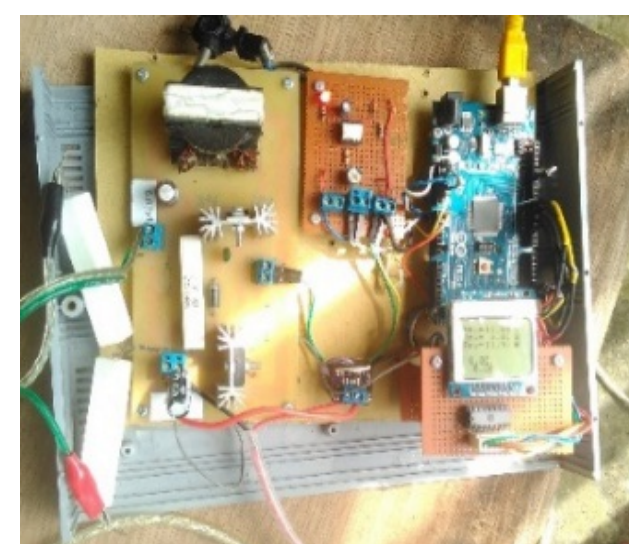

Figure 14. ANFIS MPPT realization.

\section{Result and discussion}

\subsection{ANFIS MPPT Simulation Result}

ANFIS MPPT is tested and simulated with varying climatic condition. Some parameters involved are shown in Table 3. Value of $V_{O C}$ dan $V_{M P P}$ of photovoltaic module as the effect of varying climatic condition is shown in Table 4.

Table 3. Climatic condition during simulation.

\begin{tabular}{|c|c|c|}
\hline Condition & Temperature $\left({ }^{\circ} \mathrm{C}\right)$ & Irradiation $\left(\mathrm{W} / \mathrm{m}^{2}\right)$ \\
\hline 1 & 28 & 333 \\
\hline 2 & 37 & 574 \\
\hline 3 & 51 & 972 \\
\hline 4 & 43 & 710 \\
\hline 5 & 32 & 432 \\
\hline
\end{tabular}

Table 4. Value of VOC and VMPP.

\begin{tabular}{|c|l|l|l|}
\hline Condition & $\mathrm{V}_{\mathrm{OC}}(\mathrm{V})$ & $\mathrm{k}$ & $\mathrm{V}_{\mathrm{MPP}}(\mathrm{V})$ \\
\hline 1 & 20,28 & \multirow{5}{*}{0,78} & 15,82 \\
& 20,12 & 15,69 \\
\hline 3 & 19,59 & 15,28 \\
\hline 4 & 19,88 & & 15,51 \\
\hline 5 & 20,22 & & 15,77 \\
\hline
\end{tabular}

This simulation is performed to determine the $\mathrm{V}_{\mathrm{MPP}}$ tracking performance of ANFIS MPPT. The results as seen in Fig. 15 show that ANFIS MPPT has good performance in tracking $\mathrm{V}_{\mathrm{MPP}}$ with varying climatic condition. Voltage fluctuation around $\mathrm{V}_{\mathrm{MPP}}$ is the result of ANFIS controller yield excess control signal $\Delta \mathrm{d}$ for a small value of $\theta(k)$ and $\Delta e(k)$.

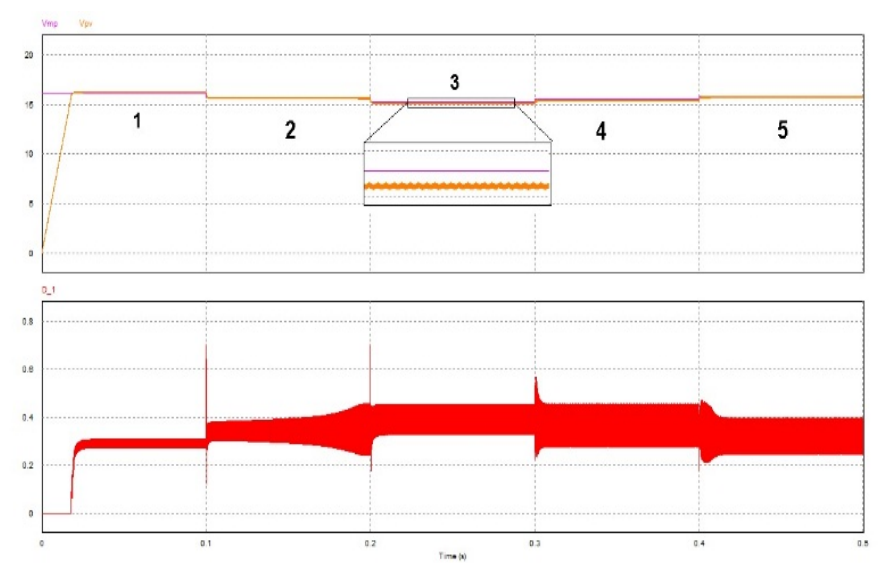

Fig.15. Result of $\mathrm{V}_{\mathrm{MPP}}$ tracking by MPPT ANFIS (above: voltage; below: duty cycle) 
Table 5. Comparison of PMPP dan P MPPT

\begin{tabular}{|c|l|c|}
\hline Condition & Parameter & Power (W) \\
\hline \multirow{2}{*}{1} & $\mathrm{P}_{\mathrm{MPP}}$ & 6.73 \\
\cline { 2 - 3 } & $\mathrm{P}$ MPPT & 6.61 \\
\hline \multirow{2}{*}{2} & $\mathrm{P}_{\mathrm{MPP}}$ & 11,21 \\
\cline { 2 - 3 } & $\mathrm{P}$ MPPT & 11,04 \\
\hline \multirow{2}{*}{3} & $\mathrm{P}_{\mathrm{MPP}}$ & 17,51 \\
\cline { 2 - 3 } & $\mathrm{P}$ MPPT & 17,50 \\
\hline \multirow{2}{*}{4} & $\mathrm{P}_{\mathrm{MPP}}$ & 13,45 \\
\cline { 2 - 3 } & $\mathrm{P}$ MPPT & 13,33 \\
\hline \multirow{2}{*}{5} & $\mathrm{P}_{\mathrm{MPP}}$ & 8.68 \\
\cline { 2 - 3 } & $\mathrm{P}$ MPPT & 8.45 \\
\hline
\end{tabular}

Based on Table 5, it can be known that $\mathrm{V}_{\mathrm{MPP}}$ value predicted by open-voltage method is close to actual $\mathrm{V}_{\mathrm{MPP}}$ proven by $\mathrm{P}$ MPPT has a small deviation from actual $\mathrm{P}_{\mathrm{MPP}}$.

\subsection{ANFIS MPPT Testing on VMPP Tracking}

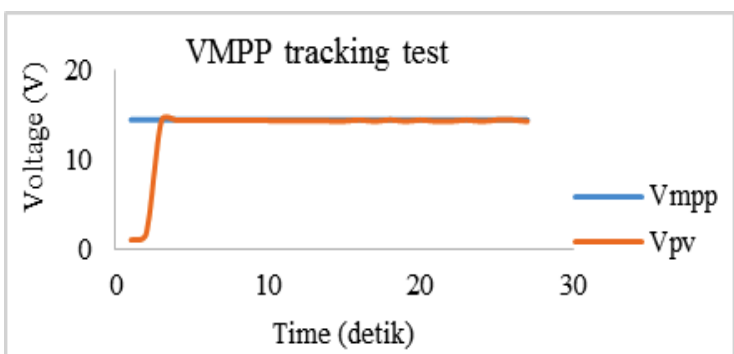

Fig. 16. Result of $\mathrm{V}_{\mathrm{MPP}}$ tracking using MPPT ANFIS hardware

The result of the experiments show that ANFIS MPPT prototype has good performance on $V_{\text {MPP }}$ tracking. The prototype is able to track setpoint with execution time $<5$ seconds from short-circuit condition for a given $\mathrm{V}_{\mathrm{MPP}}$ as displayed in Fig. 16.

\subsection{ANFIS MPPT without Solar Tracker System}

This experiment is conducted to compare power produced between ANFIS MPPT and non-MPPT system. There are three variabels measured namely Pout non-MPPT, Pin MPPT and Pout MPPT. Pout nonMPPT is power that directly delivered to the load. Pin MPPT is power obtained in the input side of buck-boost converter, moreover Pout MPPT is power obtained in the ouput side of buck-boost converter. Load used for experiment is $12 \mathrm{~V} 10 \mathrm{~W}$ incandescent lamp. The Experiments are conducted on August 3th, 2017.

\subsubsection{Experiment I}

This experiment is performed using 2 lamps as load arranged in series for each system at $11.00-13.30$.
Table 6. Output power comparison for experiment I

\begin{tabular}{|c|c|c|c|c|c|c|}
\hline \multirow{2}{*}{ No. } & \multicolumn{4}{|c|}{ MPPT } & \multirow{2}{*}{$\begin{array}{c}\begin{array}{c}\text { non- } \\
\text { MPPT }\end{array} \\
\text { Pout }(W)\end{array}$} & \multirow{2}{*}{$\begin{array}{c}\text { Pout } \\
\text { Increase } \\
(\%)\end{array}$} \\
\hline & $\begin{array}{l}\text { Duty } \\
\text { Cycle }\end{array}$ & PWM & $\begin{array}{l}\text { Pin } \\
(W)\end{array}$ & $\begin{array}{c}\text { Pout } \\
\text { (W) }\end{array}$ & & \\
\hline 1. & 0,54 & 137 & 11,69 & $\mathbf{9 , 0 8}$ & 8,5 & 6,823529 \\
\hline 2. & 0,55 & 138 & 12,54 & 9,84 & 8,91 & 10,43771 \\
\hline 3. & 0,54 & 137 & 11,65 & 9,2 & 9,07 & 1,433297 \\
\hline 4. & 0,55 & 140 & 12,61 & 9,6 & 9,22 & 4,121475 \\
\hline 5. & 0,55 & 139 & 12,53 & 9,92 & 8,71 & 13,89208 \\
\hline 6. & 0,54 & 138 & 11,94 & 9,4 & 8,55 & 9,94152 \\
\hline 7. & 0,54 & 138 & 12,31 & 9,97 & 8,73 & 14,20389 \\
\hline 8. & 0,54 & 138 & 12,19 & 9,54 & 8,93 & 6,830907 \\
\hline 9. & 0,55 & 139 & 12,53 & 10,13 & 8,9 & 13,82022 \\
\hline 10. & 0,54 & 137 & 12,28 & 9,75 & 8,6 & 13,37209 \\
\hline 11. & 0,31 & 79 & 2,32 & 1,46 & 0,88 & 65,90909 \\
\hline 12. & 0,30 & 75 & 1,99 & 1,43 & 0,86 & 66,27907 \\
\hline 13. & 0,42 & 106 & 4,78 & 4,63 & 4,62 & 0,21645 \\
\hline 14. & 0,33 & 83 & 2,84 & 1,99 & 1,11 & 79,27928 \\
\hline 15. & 0,30 & 76 & 2,3 & 1,64 & 0,7 & 134,2857 \\
\hline 16. & 0,40 & 101 & 4,59 & 3,68 & 3,6 & 2,222222 \\
\hline 17. & 0,39 & 98 & 4,18 & 3,06 & 2,97 & 3,030303 \\
\hline 18. & 0,30 & 75 & 2,04 & 1,37 & 0,54 & 153,7037 \\
\hline 19. & 0,44 & 112 & 6,46 & 5,72 & 5,19 & 10,21195 \\
\hline 20. & 0,36 & 90 & 3,75 & 2,79 & 1,95 & 43,07692 \\
\hline 21. & 0,32 & 82 & 2,8 & 2,1 & 1,91 & 9,947644 \\
\hline 22. & 0,34 & 86 & 3,04 & 2,29 & 1,08 & 112,037 \\
\hline 23. & 0,32 & 80 & 2,45 & 1,83 & 1,28 & 42,96875 \\
\hline 24. & 0,33 & 83 & 2,72 & 1,96 & 1,93 & 1,554404 \\
\hline 25. & 0,33 & 83 & 11,69 & 9,08 & 8,5 & 6,823529 \\
\hline \multicolumn{6}{|c|}{ Average Pout Increase } & 34,14997 \\
\hline
\end{tabular}

Experimental results show power delivered to the input side of buck-boost converter of ANFIS MPPT (Pin) is higher than that delivered to load in non-MPPT system. It indicated that ANFIS MPPT increases produced power from photovoltaic module. However, buck-boost converter used in ANFIS MPPT has efficiency of $70-80 \%$ thus power delivered in output side of converter is always lower than input side. According to Table 6, ANFIS MPPT system produced power gain around $34.14997 \%$ relative to the non-MPPT system when 2 lamps were used as load.

\subsubsection{Experiment /I}

This experiment is carried out using 3 lamps as load arranged in series for each system at $13.30-16.00$. 
Table 7. Output power comparison for experiment II.

\begin{tabular}{|c|c|c|c|c|c|c|}
\hline \multirow{2}{*}{ No. } & \multicolumn{4}{|c|}{ MPPT } & \multirow{2}{*}{$\begin{array}{c}\text { non- } \\
\text { MPPT } \\
\text { Pout } \\
\text { (W) }\end{array}$} & \multirow{2}{*}{$\begin{array}{c}\text { Pout } \\
\text { Increase } \\
(\%)\end{array}$} \\
\hline & $\begin{array}{l}\text { Duty } \\
\text { Cycle }\end{array}$ & PWM & $\begin{array}{l}\text { Pin } \\
\text { (W) }\end{array}$ & $\begin{array}{l}\text { Pout } \\
\text { (W) }\end{array}$ & & \\
\hline 1. & 0,47 & 119 & 6,07 & 4,48 & 4,13 & 8,474576271 \\
\hline 2. & 0,48 & 123 & 7,1 & 5,69 & 4,22 & 34,83412322 \\
\hline 3. & 0,49 & 125 & 7,4 & 5,98 & 5,15 & 16,11650485 \\
\hline 4. & 0,46 & 117 & 5,9 & 4,61 & 3,75 & 22,93333333 \\
\hline 5. & 0,47 & 120 & 6,45 & 5,13 & 4,88 & 5,12295082 \\
\hline 6. & 0,49 & 123 & 7,17 & 5,83 & 4,45 & 31,01123596 \\
\hline 7. & 0,49 & 125 & 7,56 & 6,26 & 4,6 & 36,08695652 \\
\hline 8. & 0,52 & 132 & 8,98 & 7,12 & 6,68 & 6,586826347 \\
\hline 9. & 0,53 & 133 & 9,33 & 7,58 & 4,65 & 63,01075269 \\
\hline 10. & 0,52 & 133 & 9,29 & 7,54 & 4,63 & 62,85097192 \\
\hline 11. & 0,52 & 133 & 9,02 & 7,5 & 5,58 & 34,40860215 \\
\hline 12. & 0,51 & 130 & 8,65 & 7,34 & 5,57 & 31,77737882 \\
\hline 13. & 0,25 & 63 & 1,73 & 1,46 & 0,91 & 60,43956044 \\
\hline 14. & 0,46 & 116 & 6,91 & 5,98 & 4,32 & 38,42592593 \\
\hline 15. & 0,49 & 124 & 7,32 & 6,09 & 4,25 & 43,29411765 \\
\hline 16. & 0,27 & 67 & 1,69 & 1,41 & 0,56 & 151,7857143 \\
\hline 17. & 0,48 & 121 & 6,97 & 5,93 & 4,29 & 38,22843823 \\
\hline 18. & 0,44 & 112 & 5,69 & 4,89 & 3,85 & 27,01298701 \\
\hline 19. & 0,48 & 122 & 6,75 & 5,74 & 4,33 & 32,56351039 \\
\hline 20. & 0,42 & 106 & 4,63 & 4,11 & 3,51 & 17,09401709 \\
\hline 21. & 0,32 & 80 & 2,27 & 1,97 & 1,76 & 11,93181818 \\
\hline 22. & 0,32 & 80 & 2,07 & 1,8 & 1,08 & 66,66666667 \\
\hline 23. & 0,31 & 77 & 1,98 & 1,72 & 0,97 & 77,31958763 \\
\hline 24. & 0,31 & 78 & 1,75 & 1,42 & 1,05 & 35,23809524 \\
\hline 25. & 0,30 & 76 & 7,56 & 6,26 & 4,6 & 36,08695652 \\
\hline
\end{tabular}

When using 3 lamps as load, power produced by non-MPPT system ( $\mathrm{P}$ non-MPPT) is almost equal to input side power of MPPT system (Pin) as shown in Figure 17. MPPT system increases produced power by $39.717277 \%$. It is assumed that equivalent resistance $R_{\text {eq }}$ of 3 lamps used is almost equal to optimal resistance $\mathrm{R}_{\mathrm{opt}}$ such that it make operating conditon of non-MPPT system is near MPP.

\subsubsection{Experiment III}

In this case, the experiment provided 4 lamps as load arranged in series for each system. It was conduted at 09.00 - 11.00. Experiment result show that when 4 lamps are used as load, efficiency produced by ANFIS MPPT system is $43.21 \%$ compared to the non-MPPT system. It can be known that operating condition of nonMPPT system has never reached MPP so that it produced less power.

\subsection{ANFIS MPPT Based on Solar Tracker System}

The experiment was operated using two $20 \mathrm{Wp} \mathrm{PV}$ modules as follows: Module 1 was equipped with solar tracking system and Module 2 was a fixed module. Loads used for the project consisted of $12 \mathrm{~V} 10 \mathrm{~W}$ incandescent lamps.
Table 8. Output power comparison for experiment III.

\begin{tabular}{|c|c|c|c|c|c|c|}
\hline \multirow{2}{*}{ No. } & \multicolumn{4}{|c|}{ MPPT } & \multirow{2}{*}{$\begin{array}{c}\begin{array}{c}\text { non- } \\
\text { MPPT }\end{array} \\
\text { Pout }(W)\end{array}$} & \multirow{2}{*}{$\begin{array}{c}\text { Pout } \\
\text { Increase } \\
(\%)\end{array}$} \\
\hline & $\begin{array}{l}\text { Duty } \\
\text { Cycle } \\
\end{array}$ & PWM & $\begin{array}{l}\text { Pin } \\
\text { (W) }\end{array}$ & $\begin{array}{c}\text { Pout } \\
\text { (W) }\end{array}$ & & \\
\hline 1. & 0,58 & 146 & 10,43 & 8,76 & 6,28 & 39,49 \\
\hline 2. & 0,57 & 145 & 9,97 & 8,18 & 6,21 & 31,72 \\
\hline 3. & 0,58 & 146 & 10,64 & 8,80 & 6,11 & 44,03 \\
\hline 4. & 0,58 & 147 & 10,83 & 9,35 & 5,86 & 59,56 \\
\hline 5. & 0,58 & 146 & 10,61 & 8,58 & 6,30 & 36,19 \\
\hline 6. & 0,58 & 147 & 10,83 & 9,35 & 5,62 & 66,37 \\
\hline 7. & 0,58 & 146 & 10,77 & 9,49 & 5,51 & 72,23 \\
\hline 8. & 0,57 & 146 & 10,60 & 8,88 & 4,69 & 89,34 \\
\hline 9. & 0,57 & 145 & 10,48 & 8,66 & 7,07 & 22,49 \\
\hline 10. & 0,58 & 148 & 11,08 & 9,47 & 7,01 & 35,09 \\
\hline 11. & 0,58 & 148 & 10,93 & 9,32 & 7,14 & 30,53 \\
\hline 12. & 0,58 & 148 & 10,71 & 9,33 & 6,80 & 37,21 \\
\hline 13. & 0,58 & 148 & 10,79 & 8,83 & 6,97 & 26,69 \\
\hline 14. & 0,56 & 141 & 8,72 & 7,87 & 6,50 & 21,08 \\
\hline 15. & 0,56 & 143 & 9,37 & 8,15 & 6,71 & 21,46 \\
\hline 16. & 0,58 & 148 & 11,33 & 9,49 & 7,16 & 32,54 \\
\hline 17. & 0,59 & 151 & 11,73 & 9,56 & 6,39 & 49,61 \\
\hline 18. & 0,57 & 145 & 9,86 & 7,69 & 6,01 & 27,95 \\
\hline 19. & 0,58 & 147 & 10,24 & 7,78 & 6,18 & 25,89 \\
\hline 20. & 0,59 & 150 & 10,87 & 8,58 & 6,09 & 40,89 \\
\hline 21. & 0,59 & 149 & 10,92 & 8,85 & 5,79 & 52,85 \\
\hline 22. & 0,60 & 152 & 11,94 & 9,54 & 6,38 & 49,53 \\
\hline 23. & 0,60 & 152 & 11,76 & 9,92 & 6,30 & 57,46 \\
\hline 24. & 0,60 & 152 & 11,79 & 9,52 & 6,26 & 52,08 \\
\hline 25. & 0,60 & 153 & 12,23 & 9,84 & 6,23 & 57,95 \\
\hline \multicolumn{6}{|c|}{ Average Pout Increase } & 43,21 \\
\hline
\end{tabular}

\subsubsection{Experiment I}

This experiment was conducted using only Module 1. There were two systems tested in this experiment i.e Solar Tracker with MPPT and without MPPT. The experiment was conducted on August 4th, 2017 at 09.30; 11.30; and 14.00. In this case, power gain was investigated to know the efficiency improvements.

Table 9. Average power increase of MPPT and non-MPPT system in solar tracker system.

\begin{tabular}{|c|c|c|c|c|}
\hline Load & \multicolumn{2}{|c|}{ Pout Increase (\%) } & \multirow{2}{*}{ Pout average (\%) } \\
\hline $\begin{array}{c}\mathbf{2} \\
\text { Lamps }\end{array}$ & 7,81 & 22,17 & 5,26 & 11,75 \\
\hline $\begin{array}{c}\mathbf{3} \\
\text { Lamps }\end{array}$ & 3,71 & 4,35 & 5,65 & 4,57 \\
\hline $\begin{array}{c}\mathbf{4} \\
\text { Lamps }\end{array}$ & 18,81 & 10,55 & 16,42 & 15,26 \\
\hline
\end{tabular}

Result obtained from this experiment can be seen in Table 9. It shows that ANFIS MPPT can increase power produced from photovoltaic equipped with solar tracking system. Increased average power for various load are $11.75 \%$ for 2 lamps, $4,57 \%$ for 3 lamps, and $15,26 \%$ for 4 lamps.

\subsubsection{Experiment II}

In this experiment there are two systems tested as demonstrated in Figure 17. First system is module 1 equipped with solar tracking system and ANFIS MPPT. The other one is fixed system and direct-coupled with loads. Load used in this experiment is 3 lamps connected 
in series. The experiment conducted on August 15th, 2017 at 11.00-13.00. There are three variabels measured namely Pout tracking, Pin tracking and Pout fixed. Pout tracking is power obtained in the input side of buckboost converter and Pin tracking is power obtained in the ouput side of buck-boost converter. Both of them are measured and determined from the first system. Meanwhile Pout fixed is power that directly delivered to the load in the second system.

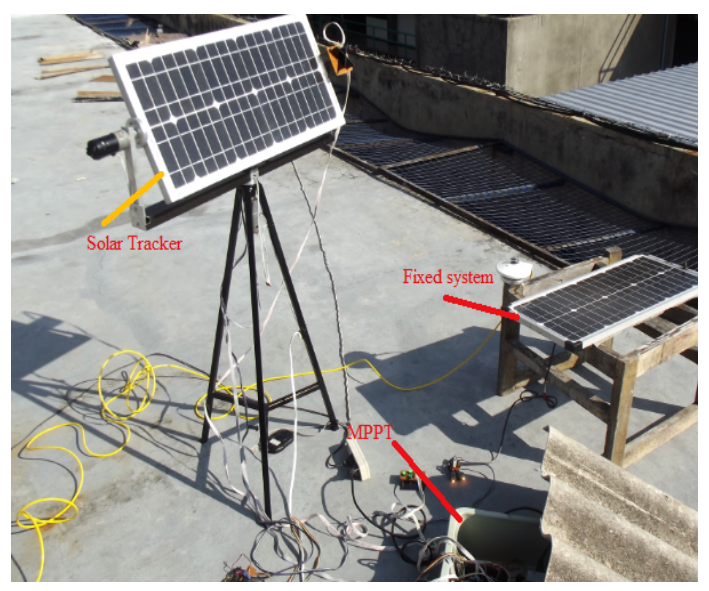

Fig. 17. Setup of Experiment II

Table 10. Power comparison of solar tracker system-ANFIS MPPT dan fixed non-MPPT system.

\begin{tabular}{|c|c|c|c|c|}
\hline \multirow{2}{*}{ No. } & \multicolumn{2}{|c|}{$\begin{array}{c}\text { Solar Tracker - MPPT } \\
\text { ANFIS }\end{array}$} & \multirow{2}{*}{$\begin{array}{c}\text { Fixed } \\
\text { Pout } \\
(W)\end{array}$} & \multirow{2}{*}{$\begin{array}{c}\text { Pout } \\
\text { Increase } \\
(\%)\end{array}$} \\
\hline & Pin (W) & Pout (W) & & \\
\hline 1. & 11,65 & 10,67 & 7,84 & 36,09694 \\
\hline 2. & 9,31 & 8,93 & 6,38 & 39,96865 \\
\hline 3. & 12,64 & 10,54 & 7,74 & 36,17571 \\
\hline 4. & 14,03 & 11,7 & 7,62 & 53,54331 \\
\hline 5. & 10,47 & 9,95 & 7,52 & 32,31383 \\
\hline 6. & 10,98 & 9,21 & 7,57 & 21,66446 \\
\hline 7. & 13,62 & 11,51 & 7,77 & 48,13385 \\
\hline 8. & 13,32 & 12,9 & 7,8 & 65,38462 \\
\hline 9. & 15,1 & 13,2 & 7,67 & 72,09909 \\
\hline 10. & 12,94 & 11,47 & 7,41 & 54,79082 \\
\hline 11. & 13,57 & 11,67 & 7,35 & 58,77551 \\
\hline 12. & 12,96 & 11,16 & 7,42 & 50,40431 \\
\hline 13. & 3,03 & 2,60 & 2,68 & $-2,98507$ \\
\hline 14. & 5,21 & 5,2 & 4,01 & 29,67581 \\
\hline 15. & 9,78 & 7,82 & 5,58 & 40,14337 \\
\hline 16. & 12,4 & 11,2 & 7,71 & 45,26589 \\
\hline 17. & 6,94 & 6,55 & 4,9 & 67,94872 \\
\hline 18. & 9,59 & 7,97 & 4,35 & 83,21839 \\
\hline 19. & 13,26 & 11,22 & 7,65 & 46,66667 \\
\hline 20. & 12,36 & 11,44 & 7,56 & 51,32275 \\
\hline & Ave & it Increas & & 46,19843 \\
\hline
\end{tabular}

It can be known from Table 10 that photovoltaic was mixed with solar tracking system and ANFIS MPPT (first system) producing 46.19843\% more power than fixed system (second system) when 3 lamps were used as load. However, there are conditions where power increase is negative which means power produced by first system is less than the second one. It is assumed that particular climatic condition during experiment was conducted, has made operating condition of second system near the MPP so that it produces power almost equal to the first one. Moreover, buck-boost converter used in ANFIS MPPT of first system has efficiency of $70-80 \%$. It causes that the output load (Pout tracking) is always lower than the input side of converter (Pin Tracking) [13-18].

\section{Conclusion}

In this study, PV module equipped with ANFIS MPPT and solar tracking system has been proposed to increase PV power production. According to experiment results, the proposed ANFIS MPPT can produce overall PV energy increase relative to the non-MPPT system by $11,75 \%$ for 2 lamps as load, 4,57\% for 3 lamps load, and $15,26 \%$ for 4 lamps load. Moreover, PV equipped with solar tracker system and ANFIS MPPT obtain $46,19843 \%$ total power increase compared to fixed PV system for 3 lamps as load.

\section{References}

1. A. Veldhuis, A. Reinders, Renewable and Sustainable Energy Reviews 52, 757-769 (2015)

2. D. Sera, R. Teodorescu, J. Hantschel, M. Knoll, IEEE Trans. Ind. Electron. 55, 2629-2637 (2008)

3. Imam. A, Ali. M, Adi. S., IREE Intl. Review of Electrical Engineering 10, 390-398 (2015)

4. M.G. Villalva, J.R. Gazoli, E.R. Filho, IEEE Trans. Power Eelectronics 24, 1198-1208 (2009)

5. S. Kolsi, H. Samet, M.B. Amar, J. Power and Energy Engineering 2, 27-34 (2014)

6. A. Dolara, R. Faranda, S. Leva, J. Electromagnetic Analysis and Applications 1, 152-162 (2009)

7. D. S. Karanjkar, S. Chatterji, S.S. L, A. Kumar, 2014 Recent Advances Engineering and Computational Sciences (RAECS), 1-6 (2014)

8. J. Ahmad, 2nd International Conference on Software Technology and Engineering (ICSTE), 247-250 (2010)

9. F. Murdianto, O. Panangsang, A. Priyadi, 2015 International Seminar on Intelligent Technology and Its Applications (ISITIA), 207-212 (2015)

10. A. Bin-halabi, A. Abdennour, H. Mashaly, Intl. J. Advanced Computer Research 4, 588-595 (2014)

11. M.A. Eltawil, Z. Zhao, Renewable and Sustainable Energy Reviews 25, 793-813 (2013)

12. Imam. A, Ali. M, Adi. S. IREMOS Intl. Review on Modeling and Simulation 8, 640-652 (2015)

13. Imam. A, Adi. S, Ali. M., BICET Brunei International Conference of Engineering and Technology, (2014)

14. E. Duran, M. Sidrach-dc-Cordona, J. Galan, J.M. Andujar, IEEE Power Electronics Specialists Conference, 2036-2042 (2008)

15. V.H. Pham, Master Thesis (2007) 
16. M.H. Tsai, Master Thesis (2012)

17. I.H. Altas, A.M. Sharaf, Intl. J. Information Technology and Intelligent Computing 1 (2007)

18. A. Desraino, Desain Maximum Power Point Tracking (MPPT) Solar Charge Controller Menggunakan Buck Converter Dengan Metode Logika Fuzzy di Buoy Weather Station. Institut Teknologi Sepuluh Nopember, Teknik Fisika. Surabaya: Institut Teknologi Sepuluh Nopember, 2016. 